\title{
The role of salal in forest regeneration problems in coastal British Columbia: problem or symptom? ${ }^{1}$
}

\author{
by Cindy E. Prescott ${ }^{2,3}$ and Toktam Sajedi ${ }^{1}$
}

\begin{abstract}
The ericaceous shrub, salal (Gaultheria shallon Pursch) is associated with forest regeneration problems on a variety of site types along the west coast of North America. On dry sites, salal is a serious competitor for water; on wet (cedar-salal) sites, salal is thought to limit nutrient availability to trees by competing, interfering with mycorrhizae and "short-circuiting" the nitrogen cycle through production of phenolic compounds. Short-term field experiments and laboratory and greenhouse studies provided some evidence of each of these effects. However, long-term results from a suite of silvicultural trials and associated ecological studies indicated that salal is not the fundamental problem for regenerating conifers on cedar-salal sites. Fertilization of cedar-salal sites caused a large and sustained response in tree growth regardless of the presence of salal, and growth responses to salal removal were much smaller than fertilization responses. Greenhouse experiments indicated that salal does not have allelopathic effects on germination or growth of conifer seedlings. In laboratory studies, salal did not demonstrate a greater capacity to take up organic $\mathrm{N}$ forms than the conifers, and molecular studies uncovered a vast diversity of mycorrhizal fungi associated with salal and hemlock roots. Together these findings indicate that the nutrient "short-circuiting" hypothesis, based on assumptions about ericoid versus non-ericoid mycorrhizal plants does not adequately describe the nutrition of plants in these ecosystems. We conclude that salal should be viewed as a symptom of the underlying problem of poor nutrient supply on cedar-salal sites, and that fertilization, rather than salal control, is the optimal solution for improving forest regeneration on these sites.
\end{abstract}

Key words: ericaceous shrubs, fertilization, scarification, allelopathy, mycorrhizae, Gaultheria shallon, nitrogen

\section{RÉSUMÉ}

Un arbuste de la famille des Éricacées, la gaulthérie shallon (Gaultheria shallon Pursch) est associé aux problèmes de régénération forestière sur différents types de station de la côte ouest de l'Amérique du Nord. Sur les stations sèches, la gaulthérie shallon est un féroce compétiteur pour l'eau, sur les stations humides (thuya-gaulthérie), on considère que celle-ci perturbe la disponibilité en éléments nutritifs des arbres par compétition, et interfere au niveau des mycorhizes et " court-circuite » le cycle de l'azote par la production de composés phénoliques. Des essais à court terme sur le terrain ainsi que des études en laboratoire et sous serre ont permis de mettre en évidence chacun de ces effets. Toutefois, les résultats à long terme d'une série de travaux en sylviculture et d'études associées en écologie ont démontré que la gaulthérie shallon ne constitue pas un problème fondamental de régénération des coniferes sur les stations de type thuyagaulthérie. La fertilisation des stations de type thuya-gaulthérie a entraîné une réaction importante et durable de la croissance des arbres sans égard à la présence de la gaulthérie shallon et les réactions de croissance suite à l'éradication de la gaulthérie shallon ont été beaucoup plus faibles que les réactions de fertilisation. Les essais sous serre ont démontré que la gaulthérie shallon ne provoque pas d'effets allélopathiques sur la germination ou la croissance des semis de coniferes. Suite aux études en laboratoire, la gaulthérie shallon n'a pas démontré une plus grande capacité à absorber les formes organiques d'azote que les coniferes et les études moléculaires ont révélé une grande diversité de champignons mycorhizateurs associés à la gaulthérie shallon et aux racines de pruche. L'ensemble de ces résultats indique que l'hypothèse du " court-circuit » des éléments nutritifs, établie à partir des prémisses que les plantes éricacées agissent différemment selon la présence ou l'absence de mycorhizes, ne décrit pas adéquatement la nutrition des plantes de cet écosystème. Nous concluons que la gaulthérie shallon devrait être considérée comme un symptôme d'un problème sousjacent d'un apport déficient en éléments nutritifs sur les stations thuya-gaulthérie et que la fertilisation, plutôt que le contrôle de la gaulthérie shallon, constitue la solution optimale pour améliorer la régénération forestière de ces stations.

Mots clés : arbustes éricacées, fertilisation, scarifiage, allélopathie, mycorhizes, Gaultheria shallon, azote

\footnotetext{
${ }^{1}$ Paper presented at the Forestry and Industrial Working Group of the Canadian Weed Science Society, November 28-29, 2006, Victoria, BC - "Today's Silviculture: Tomorrow's Forest"

${ }^{2}$ Department of Forest Sciences, Faculty of Forestry, University of British Columbia, 2005-2424 Main Mall, Vancouver, British Columbia V6T 1 Z4

${ }^{3}$ Corresponding author. E-mail: cindy.prescott@ubc.ca
} 


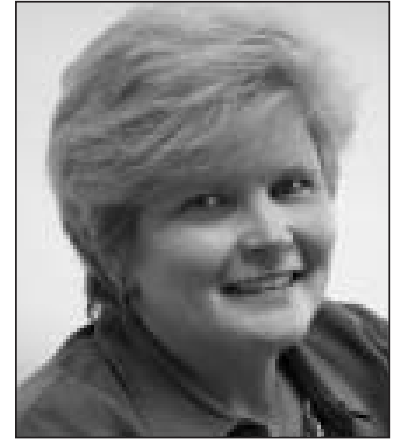

Cindy E. Prescott

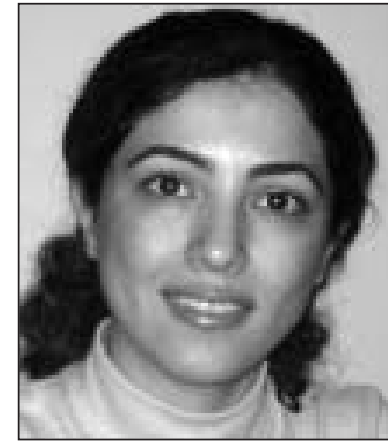

Toktam Sajedi

\section{Introduction}

Salal (Gaultheria shallon Pursch) is a native, evergreen, ericaceous shrub that occurs along the Pacific Coast of North America from the Alaska panhandle to southern California (Fraser et al. 1993). Salal grows throughout coastal British Columbia in lowland coniferous forests and open shoreline habitats in both mineral and organic soils (Province of British Columbia 2002). Podzols with deep mor humus forms are favourable to salal, but it is also found on Brunisolic, Folisolic, and organic soils (Haeussler et al. 1990). Salal forms dense covers at early stages of forest succession just after a major disturbance and then later in stand development in the understory. It tolerates a wide range of moisture and nutrient conditions, but is most abundant on nutrient-poor, slightly dry to moist sites, and on some very moist sites (Province of British Columbia 2002). Although salal responds favourably to nutrient additions (Sabhasri 1961 cited in Haeussler et al. 1990), it is restricted to decaying wood on nutrient-rich sites, presumably through competition (Klinka et al. 1989). Salal invades stands by seeding; however, rapid expansion of cover and site occupancy are related to salal's ability to spread by clonal expansion from bud banks on roots and rhizomes (Huffman et al. 1994, Tappeiner et al. 2001). Salal spreads vegetatively through layering, sprouting and suckering; cuttings of roots or stems readily form new roots and sprouts (Haeussler et al. 1990). Salal forms extensive shallow root systems and the root biomass of salal has been shown to exceed the weight of aboveground parts (Sabhasri 1961).

Like other ericaceous sites, salal-dominated sites are frequently problematic for regeneration following forest harvesting. Salal is capable of gaining near complete occupancy of a site (Haeussler et al. 1990) and is considered to be a vigorous competitor with trees for water and nutrients (Fraser et al. 1993). On dry sites, salal is believed to be a serious competitor for moisture, and several field studies have reported increases in growth and moisture status of Douglas-fir following removal of salal (Kelliher 1985, Vihanek 1985, Price et al. 1986, D’Anjou 1998, Harrington 2006). In contrast, Sabhasri (1961) reported that salal removal reduced growth of Douglas-fir in western Washington.

On wetter sites, salal is most abundant on nutrient-poor sites and the negative effect of salal on tree growth is thought to be the result of competition for nutrients (Weetman et al. 1989b, Messier and Kimmins 1990). In the CWH vm1, "a nutrient-very-poor to poor "salal phase" of site series 01 and
06 (fresh to very moist) has been identified on the west coast and north end of Vancouver Island" (Green and Klinka 1994). These "cedar-salal sites" are estimated to occur on about 100 000 ha of northern Vancouver Island in which salal dominates the understory of old-growth forests of western redcedar (Thuja plicata Donn) and western hemlock (Tsuga heterophylla [Raf.] Sarg.) (J. Barker ${ }^{4}$, personal communication). This problem was first identified in the 1960s, when clearcutlogging on northern Vancouver Island generated substantial areas of cutovers that regenerated very slowly with cedar and hemlock amongst a heavy cover of salal. To achieve more rapid regeneration, the cutovers were slash-burned to reduce slash accumulations and salal cover, and planted with Sitka spruce. The spruce plantations grew well initially, but by age six to eight years, they showed signs of severe nutrient deficiency and growth rates declined markedly. Cedar appeared to be less influenced by the nutritional problems on these sites and consequently cedar was planted thereafter. However, growth check and associated chlorosis were apparent in all species five to eight years after clearcutting and slashburning, coinciding with the expansion of salal on the cutovers. A collaborative research program involving forest companies, universities and federal and provincial forestry agencies, known as the Salal Cedar Hemlock Integrated Research Program (SCHIRP), was established in 1986 to investigate the causes of and solutions to the regeneration problem. Following is a summary of the findings of this long-term research program with respect to management of cedar-salal sites.

\section{Results from Short-Term Studies}

There were several reasons for initially suspecting that salal was the principle cause of the poor conifer growth on cedarhemlock $(\mathrm{CH})$ cutovers. Salal was extremely abundant on $\mathrm{CH}$ cutovers and much less so on adjacent cutovers of secondgrowth forests of hemlock and amabilis fir (Abies amabilis (Dougl.) Forbes) (HA) on which regeneration problems did not occur. These forests originate from a windstorm in 1908 and have dense canopies and sparse understories with very little salal. The phenomenon was similar to that of "heather check" of Sitka spruce reported in the UK and Ireland on sites dominated by the ericaceous shrub Calluna vulgaris (L.) Hull (Malcolm 1975, Carey 1977), and also similar to observations of poor conifer growth on sites dominated by Kalmia angustifolia (L.) in eastern Canada (Meades 1983). In these situations, fertilization with $\mathrm{N}$ and $\mathrm{P}$ had improved conifer growth (McIntosh 1980), so field trials were established to determine if the problem on $\mathrm{CH}$ sites was related to nutrient supply. Early results indicated a strong growth response of regenerating conifers on $\mathrm{CH}$ sites to $\mathrm{N}+\mathrm{P}$ fertilization (Fig. 1; Weetman et al. 1989a, b). Further evidence of a nutritional cause of the growth check came from measures of soil nutrient availability in cutovers - there was a marked decline in availability of these nitrogen and phosphorus in the first decade following forest harvest (Messier and Kimmins 1990, Weetman et al. 1990).

Salal was suspected to play a key role in the decline in nutrient availability on $\mathrm{CH}$ cutovers, for several reasons. The decline was coincident with the rapid expansion of salal on

\footnotetext{
${ }^{4}$ Professor Emeritus, Department of Forest Sciences, Faculty of Forestry, University of British Columbia.
} 


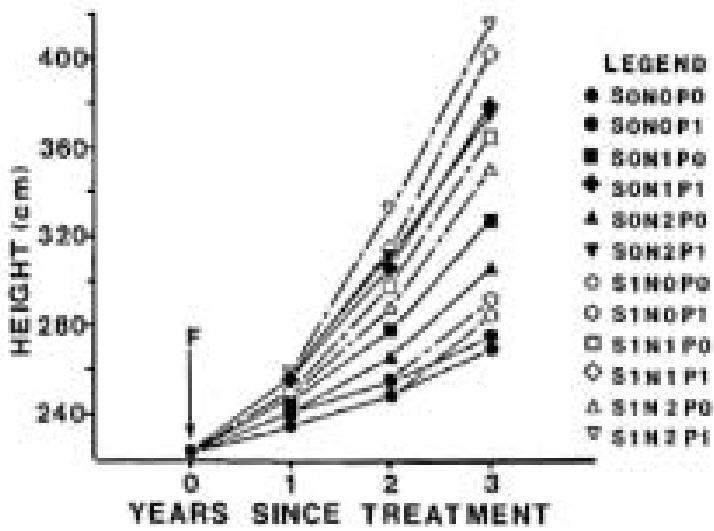

Fig. 1. Western hemlock height growth during the three years following various combinations of salal removal (S1) and fertilization with ammonium nitrate (N1) or urea (N2) and triple superphosphate (P1). From Weetman et al. 1989b.

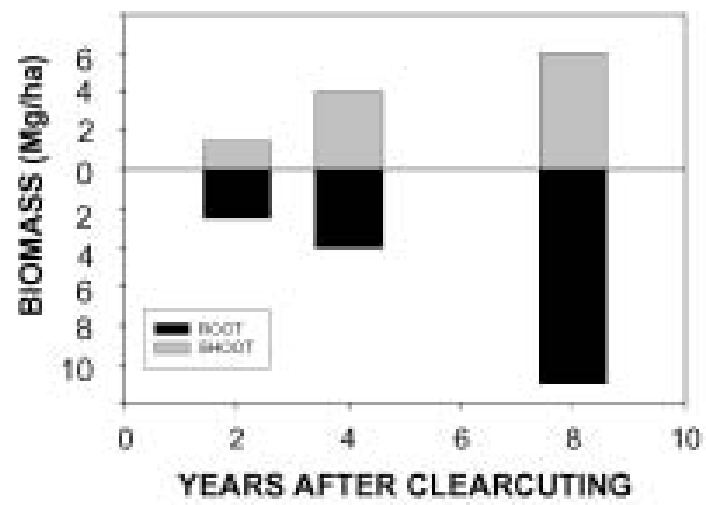

Fig. 2. Above- and below-ground biomass of salal on a post-harvest chronosequence of $\mathrm{CH}$ cutovers ladapted from Messier and Kimmins 1990).

$\mathrm{CH}$ cutovers during the first eight years after clearcut-harvesting. Between two and eight years after harvest, the biomass of ground vegetation $(70 \%$ salal) on $\mathrm{CH}$ cutovers increased from about $4 \mathrm{Mg} / \mathrm{ha}$ to $17 \mathrm{Mg} / \mathrm{ha}$, of which over $10 \mathrm{Mg} / \mathrm{ha}$ was root biomass (Fig. 2; Messier and Kimmins 1990). With this large root biomass, salal would be a serious competitor for soil nutrients, and indeed the $\mathrm{N}$ content of salal increased from 20 to $70 \mathrm{~kg} \mathrm{~N} / \mathrm{ha}$ and from less than $2 \mathrm{~kg} \mathrm{P} / \mathrm{ha}$ to more than $6 \mathrm{~kg} \mathrm{P} / \mathrm{ha}$ between two and eight years after clearcutting (Messier and Kimmins 1990). More evidence of a strong competitive effect of salal came from a comparison of growth performance of two- and four-year-old hemlock and cedar saplings and salal leaf area index on $\mathrm{CH}$ and HA cutovers (Fraser et al. 1995). Growth of hemlock was strongly nega-

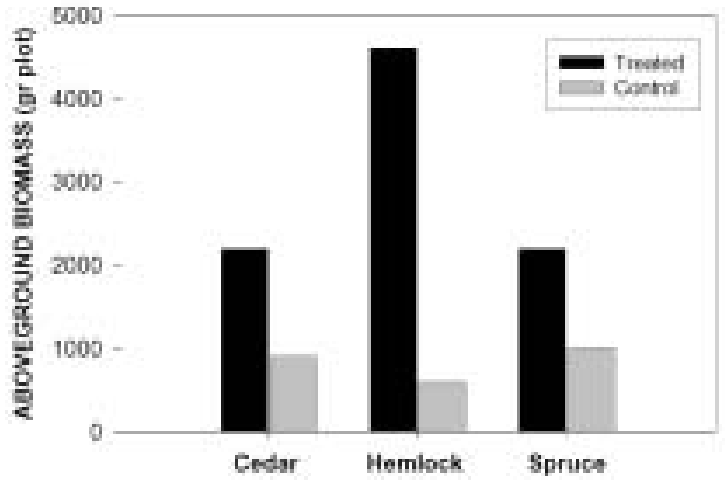

Fig. 3. Above-ground biomass of cedar, hemlock and spruce trees six years after planting on a $\mathrm{CH}$ cutover, with and without clipping and trenching to remove salal. From Chang et al. 1996.

tively correlated with abundance of salal, although cedar growth was only weakly related to salal abundance. Removal of vegetation (mostly salal) surrounding individual conifer seedlings through trenching and clipping led to a significant increase in growth of spruce, hemlock and cedar saplings (Fig. 3) and increased availability of $\mathrm{N}$ and P (Messier 1993, Chang et al. 1996). However, manual removal of salal from field plots followed by Garlon applications did not improve conifer growth in the first three years following treatment (Weetman et al. 1990).

It was also hypothesized that salal may have allelopathic effects on conifers, through the production of tannins and other phenolic compounds, as had been considered for heather in the UK (Read 1984) and Kalmia in Newfoundland (Meades 1983). Indeed, tannins were identified in the leaves, roots, flowers, berries and litter of salal (deMontigny 1992). In a laboratory bioassay, a 5\% solution of salal flowers and berries significantly reduced germination of spruce and cedar seeds, and seedlings of spruce, cedar and hemlock watered with the salal solution produced less biomass than control seedlings during a 12-week bioassay. When placed in the salal solution, roots of mature cedar and hemlock took up only $9 \%$ as much ${ }^{32} \mathrm{P}$ as did similar roots in a $\mathrm{P}$ solution without salal.

There was also some evidence that salal might interfere with the mycorrhizal fungi of conifers. Salal has ericoid mycorrhizae, while hemlock and cedar are ectomycorrhizal and VAM, respectively. In a pot trial, one-year-old cedar seedlings grown with salal had 10\% less VAM colonization than seedlings grown only with cedar or grown with salal in pots in which the roots of the two species were separated by a wooden divider (L.D. Husted ${ }^{5}$, unpublished data). Three species of ectomycorrhizal fungi inoculated onto agar plates with one of six ericoid mycorrhizal fungi (including two isolates from salal roots) were consistently inhibited by the eri-

${ }^{5}$ Research scientist, Canadian Pacific Forest Products Limited, Victoria, BC. 


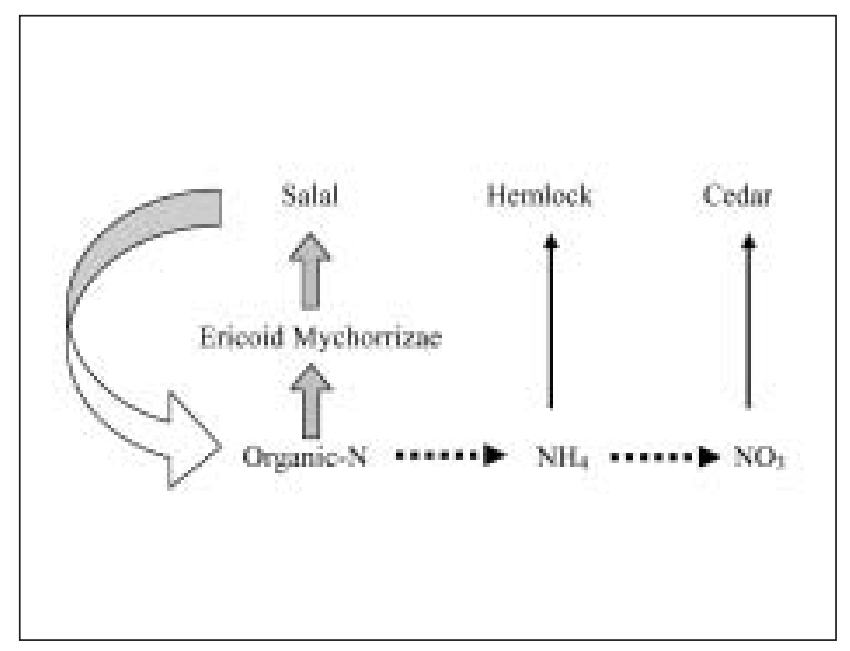

Fig. 4. Nutrient short-circuiting hypothesis in which salal deprives cedar and hemlock of their preferred nitrogen sources (nitrate and ammonium respectively] by interfering with mineralization of $\mathrm{N}$ and taking up organic forms of $\mathrm{N}$.

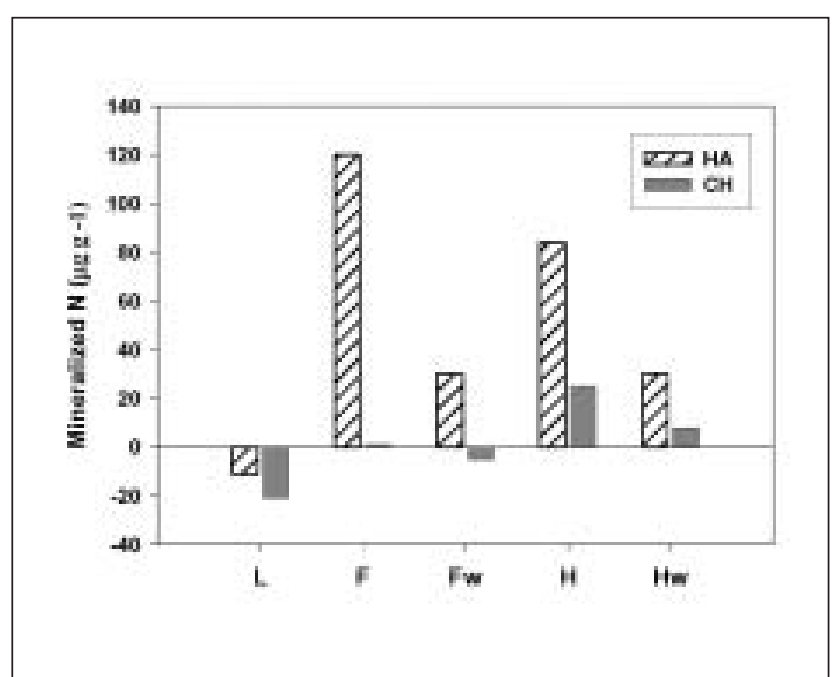

Fig. 5. Amounts of $\mathrm{N}$ mineralized from forest floors from $\mathrm{CH}$ and $\mathrm{HA}$ forests during a 40-day aerobic laboratory incubation. From Prescott et al. 1993.

Table 1. Cell percent colonization of salal plants inoculated with five root-associated fungi. Each value is the mean (standard deviation) of 10 samples; values with the same letter are not significantly different.

\begin{tabular}{|c|c|c|c|c|c|}
\hline \multirow[b]{2}{*}{ Plants inoculated with } & \multicolumn{5}{|c|}{ Nitrogen Sources } \\
\hline & Ammonium & Glutamine & Glutathione & BSA & N-free \\
\hline Unknown 1 & $\begin{array}{c}\text { 18gh } \\
(3)\end{array}$ & $\begin{array}{c}20 \mathrm{gh} \\
(3)\end{array}$ & $\begin{array}{l}95 a \\
(2)\end{array}$ & $\begin{array}{l}96 a \\
(2)\end{array}$ & $\begin{array}{l}95 a \\
(2)\end{array}$ \\
\hline Oidiodendron griseum & $\begin{array}{c}20 \mathrm{gh} \\
(6)\end{array}$ & $\begin{array}{c}19 \mathrm{gh} \\
(2)\end{array}$ & $\begin{array}{c}\text { 80de } \\
(7)\end{array}$ & $\begin{array}{c}94 \mathrm{ab} \\
(3)\end{array}$ & $\begin{array}{c}93 \mathrm{abc} \\
(5)\end{array}$ \\
\hline Acremonium strictum & $\begin{array}{c}11 \mathrm{~h} \\
(2)\end{array}$ & $\begin{array}{l}11 \mathrm{gh} \\
(2)\end{array}$ & $\begin{array}{c}83 \mathrm{de} \\
(4)\end{array}$ & $\begin{array}{l}63 f \\
(6)\end{array}$ & $\begin{array}{c}86 \mathrm{bcde} \\
(2)\end{array}$ \\
\hline Unknown 2 & $\begin{array}{c}\text { 18gh } \\
(2)\end{array}$ & $\begin{array}{c}17 \mathrm{gh} \\
(2)\end{array}$ & $\begin{array}{c}82 \mathrm{de} \\
(5)\end{array}$ & $\begin{array}{c}\text { 84cde } \\
\text { (4) }\end{array}$ & $\begin{array}{c}90 \mathrm{bcde} \\
(4)\end{array}$ \\
\hline Hymenoscyphus ericae & $\begin{array}{c}17 \mathrm{gh} \\
(2)\end{array}$ & $\begin{array}{c}20 \mathrm{gh} \\
\text { (3) }\end{array}$ & $\begin{array}{c}84 c d e \\
(5)\end{array}$ & $\begin{array}{c}81 \mathrm{de} \\
(6)\end{array}$ & $\begin{array}{l}79 \mathrm{e} \\
(7)\end{array}$ \\
\hline
\end{tabular}

coid mycorrhizal fungi, while none of the ericoid mycorrhizal fungi were inhibited by the ectomycorrhizal fungi (Xiao 1994).

It was also thought that salal might "short-circuit" the $\mathrm{N}$ cycle, as later described in the pygmy pine forests of California (Northup et al. 1995). According to this hypothesis (Fig. 4), by secreting polyphenolic compounds, which are known to interfere with decomposition and nutrient mineralization, salal could inhibit the mineralization of organic $\mathrm{N}$ compounds to ammonium and nitrate, the $\mathrm{N}$ forms preferred by hemlock and cedar, respectively. Salal, by virtue of its ericoid mycorrhizal associates is able to take up the organic forms of $\mathrm{N}$, and in so doing, starves the conifers of N. Several observations were consistent with this hypothesis. Humus from $\mathrm{CH}$ forests had higher concentrations of several phenolic acids (deMontigny 1992). Forest floor $\mathrm{F}$ and $\mathrm{H}$ layers in $\mathrm{CH}$ forests had much lower rates of net $\mathrm{N}$ mineralization than in HA forests (Prescott et al. 1993; Fig. 5), and contained about 20 times more soluble organic $\mathrm{N}$ than ammonium and nitrate (Hannam and Prescott 2003). Xiao and Berch (1999) found that the colonization rate of four species of ericoid mycorrhizae on salal was higher when provided with complex organic $\mathrm{N}$ sources (glutathione and bovine serum albumin) than simple organic $\mathrm{N}$ (glutamine) or ammonium (Table 1).

Collectively, these initial findings from SCHIRP field trials and ecological studies provided strong evidence that competition, allelopathy and interference from salal were the principle causes of poor nutrient supply and conifer growth on $\mathrm{CH}$ cutovers. As a consequence, operational practices of the licensees focused on reducing the negative effects of salal in addition to alleviating nutrient supply constraints through fertilization. Herbicides were not used, but treatments such as slashburning or scarification were applied to set back the salal prior to planting hemlock. This was followed by single or 


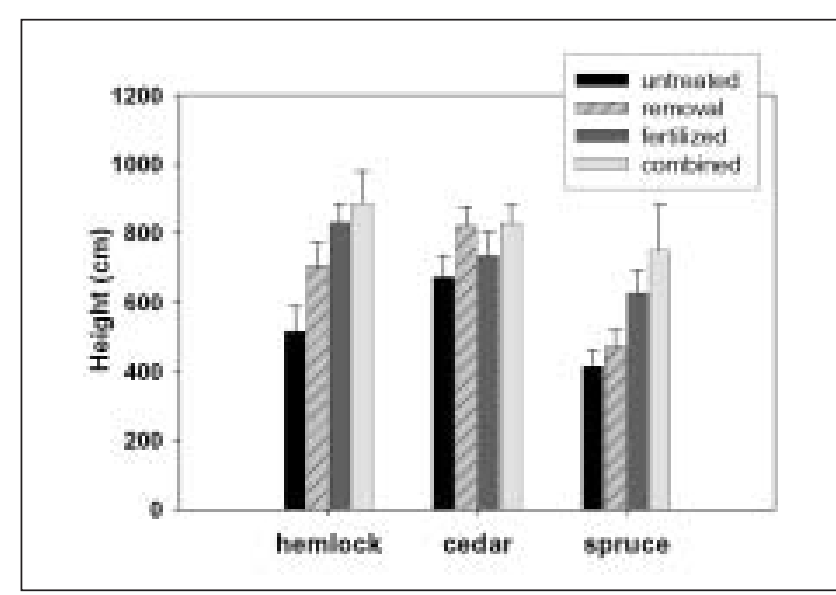

Fig. 6. Height growth of cedar, hemlock and spruce trees following treatment application in the 13 years following fertilization or salal removal (or both) on a $\mathrm{CH}$ cutover. From Bennett et al. 2003.

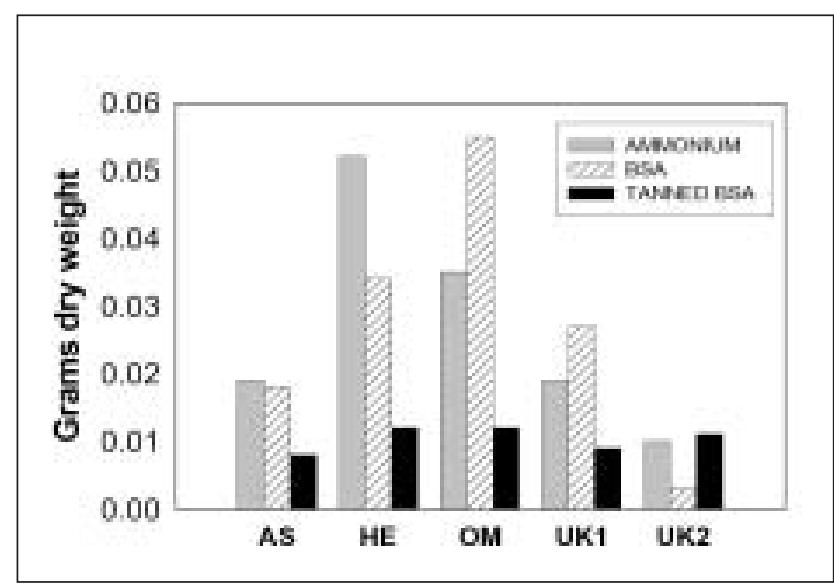

Fig. 7. Mass of mycelium in liquid culture on three different $N$ sources of five ericoid mycorrhizal fungi $(A S=$ Acremonium strictum; HE = Hymenoscyphus ericae; OM = Oidiodendron Maius; UK1 = Unknown 1; UK2 = Unknown 2).

double fertilizer applications to hasten crown closure, at which point the salal would be shaded out. It was hoped that once the salal was eliminated, nutrient supply and availability would be improved, and further fertilization would not be necessary. However, results from the continued monitoring of the field trials for more than a decade have not been entirely consistent with the expected benefits of salal removal.

\section{Results from Long-Term Studies}

In keeping with initial responses from the field trails, the long-term (10+years) effects of salal removal on growth of conifers have been smaller than that of fertilization (Bennett et al. 2003; Fig. 6). Height growth of hemlock and spruce during the 13 years after treatment was significantly greater in plots fertilized with $\mathrm{N}+\mathrm{P}$, but not in plots in which the salal had been removed. Cedar and hemlock seedlings grown in forest floor from salal-removal plots grew at the same rate as those from control plots, whereas seedlings in forest floor from fertilized plots grew significantly faster (Bennett et al. 2003). Rates of $\mathrm{C}$ and $\mathrm{N}$ mineralization in the forest floors were also elevated in fertilized plots, but not in salal-removal plots (Bradley et al. 2000). These observations indicated that $\mathrm{N}+\mathrm{P}$ fertilization had stimulated a long-term increase in nutrient availability on $\mathrm{CH}$ sites, but salal removal had not.

These large growth responses of conifers to fertilization on $\mathrm{CH}$ sites occurred without a reduction in salal abundance. In fact, in plots fertilized with $\mathrm{N}+\mathrm{P}$ (or organic residuals), there was an obvious increase in salal growth and vigour until the crowns closed and began shading out the salal. The only reduction in salal growth occurred in plots repeatedly fertilized with large amounts of ammonium nitrate (Bennett et al. 2004). The most surprising positive response of salal was to the application of straw to a depth of $25 \mathrm{~cm}$. This treatment repeated an earlier experiment in Quebec in which a single application of straw to a nutrient-deficient jack-pine stand killed the ericaceous ground vegetation (Kalmia) and promoted a long-term increase in tree growth and $\mathrm{N}$ availability (Prescott et al. 1995, Weetman et al. 1995). Unlike the Kalmia, the salal was only temporarily covered and responded positively to the straw application, as did Epilobium angustifolia (Prescott and Zabek 1997). Foliar concentrations of N, P and $\mathrm{K}$ significantly increased in both salal and cedar in strawamended plots, and the cedar height increment exceeded that observed in other fertilization treatments $(\mathrm{N}+\mathrm{P}$, biosolids, fish silage). This also suggests that the growth response of jack pine in the earlier experiment may have actually been a response to the fertilization effect of the straw rather than control of the Kalmia. These observations have demonstrated that salal control is not necessary for improving productivity of $\mathrm{CH}$ sites; alleviating the nutrient deficiency through addition of $\mathrm{N}$ and $\mathrm{P}$ (at 200 and $50 \mathrm{~kg} / \mathrm{ha}$ respectively) is sufficient to boost the productivity of the conifers to acceptable levels.

Results from further ecological studies have also caused us to question some of the conclusions from the early studies about the degree to which salal contributes to poor conifer growth on $\mathrm{CH}$ sites. Recent ecological studies have indicated that salal does not interfere with the growth and nutrition of conifers as much as earlier thought. Mallik and Prescott (2001) found no effect of salal litter or litter leachate on hemlock germination and primary growth, nor did salal litter affect the growth of cedar or hemlock seedlings in pots. Growth of cedar and hemlock seedlings was reduced when they were grown with salal. They concluded that competition, especially root competition, is the main mechanism by which salal affects the growth of conifers.

Tests of the "short-circuiting" hypothesis have not provided convincing evidence that this phenomenon is prevalent on $\mathrm{CH}$ sites. Berch ${ }^{6}$ (unpublished data) measured mycelial growth of five ericoid mycorrhizal fungi on $\mathrm{N}$ sources of increasing complexity (ammonium, BSA and tanned BSA) and found that they all grew poorly on tanned BSA but grew equally well on the other substrates (Fig. 7). Percent colonization of in vitro salal roots was greatest in BSA and least in ammonium. Bennett and Prescott (2004) tested the hypothesis that salal, by virtue of its ericoid mycorrhizae, would take up more $\mathrm{N}$ from complex organic $\mathrm{N}$ compounds than would cedar or hemlock. Seedlings of the three species were provided with solutions of ${ }^{15} \mathrm{~N},{ }^{13} \mathrm{C}$-labelled nitrate, ammonium, glutamic acid, protein, and protein-tannin N. All three species

${ }^{6}$ Shannon M. Berch, Research Scientist, Research Branch, BC Ministry of Forests and Range, Victoria, BC. 
Table 2. Summary of evidence pertaining to each of the three mechanisms by which salal was thought to negatively affect conifer growth on cedar-hemlock (CH) sites. Findings in the white box are consistent with the hypothesis; findings in the grey box are inconsistent with the hypothesis.

\begin{tabular}{|c|c|c|}
\hline Competition & Allelopathy & Nutrient Short-circuiting \\
\hline $\begin{array}{l}\text { salal biomass and } \mathrm{N} \text { content increase as } \\
\text { nutrient availability declines after harvesting } \\
\text { (Messier and Kimmins 1990) }\end{array}$ & $\begin{array}{l}\text { tannins from salal inhibit conifer } \\
\text { germination and growth } \\
\text { (deMontigny 1992) }\end{array}$ & $\begin{array}{l}\text { higher phenolic acids in CH humus } \\
\text { than HA humus (deMontigny } 1992 \text { ) }\end{array}$ \\
\hline $\begin{array}{l}\text { hemlock growth negatively } \\
\text { correlated with salal cover } \\
\text { (Fraser et al. } 1995 \text { ) }\end{array}$ & $\begin{array}{l}\text { P uptake by conifer roots reduced } \\
\text { when in salal solution (deMontigny 1992, } \\
\text { Hannam and Prescott 2003) }\end{array}$ & $\begin{array}{l}\text { Higher dissolved organic } \mathrm{N} \text {, } \\
\text { lower mineral } \mathrm{N} \text { in } \mathrm{CH} \text { forest floors }\end{array}$ \\
\hline $\begin{array}{l}\text { clipping salal improves } \\
\text { conifer growth } \\
\text { (Chang et al. 1996) }\end{array}$ & $\begin{array}{l}\text { ericoid mycorrhizal fungus from salal } \\
\text { inhibits ecto fungus from hemlock } \\
\text { (Xiao 1994) }\end{array}$ & $\begin{array}{l}\text { greater colonization of ericoid mycorrhizae } \\
\text { on salal when given complex organic } \mathrm{N} \\
\text { (Xiao 1994) }\end{array}$ \\
\hline $\begin{array}{l}\text { conifer's seedling grow less in } \\
\text { pots with salal present } \\
\text { (Mallik and Prescott 2001) }\end{array}$ & $\begin{array}{l}\text { no effect of salal litter and leachate on } \\
\text { conifer seedling growth in pots } \\
\text { (Mallik and Prescott 2001) }\end{array}$ & $\begin{array}{l}\text { ericoid mycorrhizal fungi do not } \\
\text { prefer organic } \mathrm{N} \text { to ammonium } \\
\text { (Berch unpublished) }\end{array}$ \\
\hline
\end{tabular}

large growth responses of conifers to fertilizer without salal removal (Prescott and Zabek 1997, Blevins et al. 2006, Negrave and Prescott 2007)

salal does not take up more organic $\mathrm{N}$

than do conifers (Bennett and Prescott 2004)

salal eradication does not substantially improve conifer growth or nutrient supply (Bradley et al. 2000, Bennett et al. 2003 )

took up nitrate and ammonium in the largest amounts, and smaller amounts of the $\mathrm{N}$ from organic $\mathrm{N}$ compounds were absorbed by all three species (Fig. 8). These studies do not provide evidence that salal has a greater capacity to take up organic $\mathrm{N}$ forms than do the conifers. Recent molecular studies have demonstrated a vast diversity of mycorrhizal fungi associated with salal and hemlock roots (Monreal et al. 1999, Berch et al. 2002), suggesting that demonstrated differences in $\mathrm{N}$-uptake abilities of the few culturable fungal species may be of little relevance to the overall nutrition of these plants.

Although none of these experiments on its own is sufficient to refute the hypothesis, the weight of evidence at this time indicates that salal is not the primary cause of the poor nutrient supply on cedar-salal sites. Several other potential contributing factors have been proposed and tested. It was thought that the presence of cedar in $\mathrm{CH}$ forests might contribute to low nutrient availability, as cedar foliage decays slower than that of other species (Keenan et al. 1996), which could lead to nutrients being tied up in the forest floor. However, experimental tests of this hypothesis in singlespecies plantations indicate that cedar does not create nutrient-poor forest floors (Prescott et al. 2000, Prescott and Vesterdal 2005). In fact, cedar's ability to grow well on nutrient-poor $\mathrm{CH}$ sites, particularly in the absence of fertilization, makes it preferable to hemlock if fertilization is not planned.

It was also suggested that the lack of windthrow disturbance (hence soil mixing) in old-growth $\mathrm{CH}$ forests, allowed progressive immobilization of nutrients in humus, with a resulting decline in nutrient availability in $\mathrm{CH}$ forests (Prescott and Weetman 1994). However, experimental tests of this hypothesis showed little effect of soil mixing on nutrient availability (Keenan et al. 1994), and scarification and cultivation trials have shown little benefit to tree growth (Blevins and Prescott 2002).

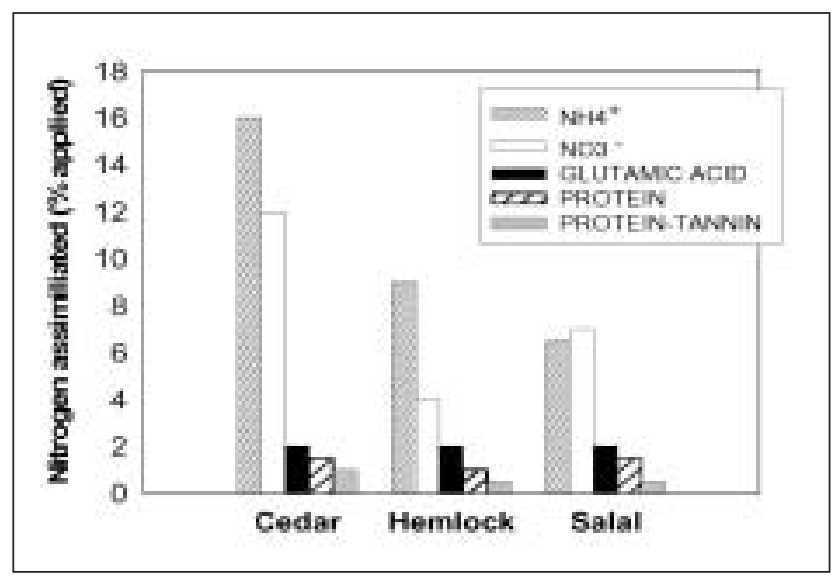

Fig. 8. Nitrogen uptake by cedar, hemlock and salal during the first 24 hours after injection of 15-N-labelled organic and inorganic $\mathrm{N}$ solutions into the forest floor around the potted plants. Values are means + SEM. Different letters indicate significantly different treatment means based on ANOVA GLM procedure $(P<$ 0.05, $n=5$-7). From Bennett and Prescott 2004.

While testing (and at least partially disproving) each of these hypotheses, researchers made a number of findings, which together, strongly indicate that $\mathrm{CH}$ sites are wetter than HA sites, and that this factor may be the primary cause of the nutrient supply problem. For example, deMontigny (1992) found greater frequency of gleyed horizons in $\mathrm{CH}$ forests and hydromors, which reflect fluctuating, stagnation or slowly moving water close to the ground surface. Battigelli et al. (1994) found lower fauna abundance and biomass and larger populations of copepods, which are aquatic animals, in $\mathrm{CH}$ forests. During measurements of nitrogen mineralization in 
forest floors of CH and HA sites (Prescott et al. 1993), it was observed that $\mathrm{CH}$ forest floor layers usually contained more than $80 \%$ water, while HA forest floors had less than $80 \%$ water. Similar work in other ecosystems has demonstrated a cut-off for net $\mathrm{N}$ mineralization at about $80 \%$ water. Bothwell et al. (2001) documented tremendously fast growth of shore pine on $\mathrm{CH}$ sites relative to other conifers. Shore pine has root lenticels that aid in aeration, and is usually found in coastal bogs. A GIS study of northern Vancouver Island (Lavery and Albani 2000) demonstrated that abundance of cedar (hence $\mathrm{CH}$ sites) increases near swamps and bogs. Finally, it was found that cedar is actually not a late-successional species (Weber et al. 2003). As such the dominance of cedar on $\mathrm{CH}$ sites may be related to these sites being wetter, and not to their being older and undisturbed, as previously thought. Thus, the current hypothesis for the poor productivity of $\mathrm{CH}$ sites is that their slightly lower slope position causes them to have excess moisture, resulting in incomplete decomposition, immobilization of nutrients into humus, poor nutrient supply and slow tree growth. This hypothesis is currently being tested in laboratory microcosms and a field drainage trail.

\section{Conclusions}

In sum, results from long-term studies lead us to conclude that salal is not the fundamental problem for regenerating conifers on cedar-salal sites - the fundamental problem is poor nutrient supply. Salal may make the situation worse for conifers by competing for nutrients, but removing or controlling the salal is not the optimal solution for improving the productivity of these sites. The nutrient supply problem for hemlock can best be overcome by fertilization with $\mathrm{N}$ and $\mathrm{P}$, without controlling salal, which recedes once the crowns close in fertilized stands. Cedar growth is not as greatly affected by nutrient supply and appears to regenerate successfully (albeit slowly) in the absence of treatment. Salal, by virtue of its ability to tolerate nutrient-poor conditions, may be used to indicate sites on which tree productivity could be enhanced through fertilization. Our findings of beneficial effects of fertilization with $\mathrm{N}+\mathrm{P}$ (or organic residuals) on conifers and salal suggest an opportunity for co-management of salal and conifers to provide floral-quality salal in fertilized areas until the time of crown closure.

These conclusions do not apply to salal-dominated sites in drier subzones, in which inadequate moisture is the primary constraint to tree growth (usually Douglas-fir). In this situation, amendment with the limiting resource (water) is not possible, so removal or control of the salal may be a viable management strategy. The variance in conclusions based on initial impressions and short-term studies, with those resulting from a long-term comprehensive research effort highlight the value of long-term trials and sustained investment in research.

\section{Acknowledgements}

In this article we have synthesized the relevant findings that arose through the efforts of the many SCHIRP scientists and students listed in the citations. Deserving of special mention is our industry partner, Western Forest Products, Inc., in particular Dr. John Barker and Ms. Annette Van Niejenhuis, whose curiosity and commitment to science-based forest management made this research happen. Funding for the research described in this article was primarily provided by the Natural Sciences and Engineering Council of Canada, Forest Renewal BC, FIA Forest Science Program, Western Forest Products, Inc., BC Ministry of Forests and the Canadian Forest Service.

\section{References}

Battigelli, J.P., S.M. Berch and V.G. Marshall. 1994. Soil fauna communities in two distinct but adjacent forest types on northern Vancouver Island, British Columbia. Can. J. For. Res. 24: 1557-1566. Bennett, J.N., L.L. Blevins, J.E. Barker, D.P. Blevins and C.E. Prescott. 2003. Long-term increases in tree growth and nutrient supply following fertilization and vegetation control of salal-dominated cedar-hemlock stands on Vancouver Island. Can. J. For. Res. 33: 1516-1524.

Bennett, J.N. and C.E. Prescott. 2004. Organic and inorganic nitrogen nutrition of western redcedar, western hemlock and salal in mineral N-limited cedar-hemlock forests. Oecologia 141: 468-476.

Berch, S.M., T.R. Allen and M.L. Berbee. 2002. Molecular detection, community structure and phylogeny of ericoid mycorrhizal fungi. Plant and Soil 244: 55-66.

Blevins, L.L. and C.E. Prescott. 2002. Salal Cedar Hemlock Integrated Research Program: Research Update \#2. Faculty of Forestry, UBC.

Blevins L.L., C.E. Prescott and A. Van Niejenhuis. 2006. The roles of nitrogen and phosphorus in increasing productivity of western hemlock and western redcedar plantations on northern Vancouver Island. For. Ecol. Managem. 234: 116-122.

Bradley, R.L., B.D. Titus, C.M. Preston and J.N. Bennett. 2000. Improvement of nutritional site quality 13 years after single application of fertiliser $\mathrm{N}$ and $\mathrm{P}$ on regenerating cedar-hemlock cutovers on northern Vancouver Island, B.C. Plant and Soil 223: 195-206.

Bothwell, K.S., C.E. Prescott and M.D. Jones. 2001. Factors contributing to the superior growth and $\mathrm{N}$ nutrition of 11-year-old lodgepole pine compared to Sitka spruce on a N-poor cedar-hemlock cutover. Can J. For. Res. 31: 1272-1279.

Carey, M.L. 1977. Nutritional disorders in Sitka spruce in the Republic of Ireland. Ir. For. 34: 40-47.

Chang, S.X., G.F. Weetman and C.M. Preston. 1996. Understory competition effect on tree growth and biomass allocation on a coastal old-growth forest cutover site in British Columbia. For. Ecol. Managem. 83: 1-11.

D'Anjou, B.N. 1998. Effect of herbicide, site preparation and fertilization on salal and Douglas-fir growth on dry sites -10 year results. FRBC Summary report. BC Ministry of Forests, Victoria, BC.

deMontigny, L. 1992. An investigation into the factors contributing to the growth check of conifer regeneration on northern Vancouver Island. Ph.D. Thesis, Dept. of Forest Sciences, University of British Columbia, Vancouver, BC. 191 p.

Fraser, L.H., C.P. Chanway and R. Turkington. 1995. The competitive role of Gaultheria shallon on planted western hemlock and western red cedar saplings on northern Vancouver Island. For. Ecol. Managem. 75: 27-39.

Fraser, L., R. Turkington and C.P. Chanway. 1993. The biology of Canadian weeds. 102. Gaultheria shallon Pursh. Can. J. Plant Sci. 73: 1233-1247.

Green, R.N. and K. Klinka. 1994. A field guide to site identification and interpretation for the Vancouver Forest Region. Land Management Handbook Number 28. BC Ministry of Forests, Victoria, BC. 285 p.

Hannam, K. and C.E. Prescott. 2003. Soluble organic nitrogen in forests and adjacent clearcuts in British Columbia, Canada. Can. J. For. Res. 33: 1709-1718.

Haeussler, S., D. Coates and J. Mather. 1990. Authecology of common plants in British Columbia: A literature review, Canadian Cataloguing in Publication Data 272: 96-102. 
Harrington, T.B. 2006. Five-year growth responses of Douglas-fir, western hemlock, and western redcedar seedlings to manipulated levels of overstory and understory competition. Can. J. For. Res. 36: 2439-2453.

Huffman, D.W., J.C. Tappeiner II and J.C. Zasada. 1994. Regeneration of salal (Gaultheria shallon) in the central Coast Range forests of Oregon. Can. J. Bot. 72: 39-51.

Keenan, R.J., C. Messier and J.P. Kimmins. 1994. Effects of clearcutting and soil mixing on soil properties and understorey biomass in western red cedar and western hemlock forests on northern Vancouver Island, Canada. For. Ecol. Managem. 68: 251-261.

Keenan, R.J., C.E. Prescott, J.P. Kimmins, J. Pastor and B. Dewey. 1996. Litter decomposition in western red cedar and western hemlock forests in northern Vancouver Island, British Columbia. Can. J. Bot. 74: 1626-1634.

Kelliher, F.M. 1985. Salal understory removal effects on the soil water regime and tree transpiration rates in a Douglas-fir forest. Ph.D. thesis, Univ. B.C., Vancouver, BC.

Klinka, K., V.J. Krajina, A. Ceska and A.M. Scagel. 1989. Indicator Plants of Coastal British Columbia. UBC Press, Vancouver, BC. 288 p. Lavery, J. and M. Albani. 2000. Hypothesis-testing of Ecological Theories for TFL $6 \mathrm{~b}$ (Northern Vancouver Island) Using GIS techniques. Unpublished report.

Malcolm, D.C. 1975. The influence of heather on silvicultural practice - an appraisal. Scott. For. 29: 14-24.

Mallik, A.U. and C.E. Prescott. 2001. Growth inhibitory effects of salal (Gaultheria shallon) on western hemlock and western red cedar: allelopathy or competition? Agron. J. 93: 85-92.

Meades, W.J. 1983. The origin and successional status of anthropogenic dwarf shrub heath in Newfoundland. Adv. Space Res. 2: 97-101.

McIntosh, R. 1980. Fertilizer treatment of Sitka spruce in the establishment phase in upland Britain. Scott. For. 35: 3-13.

Messier, C., 1993. Factors limiting early growth of western red cedar, western hemlock and Sitka spruce seedlings on ericaceous-dominated clearcut sites in coastal British Columbia. For. Ecol. Managem. 60: 181-206.

Messier, C. and J.P. Kimmins. 1990. Nutritional stress in Picea sitchensis plantations in coastal British Columbia: the effects of Gaultheria shallon and declining site fertility. Wat. Air Soil Pollut. 54: 257-267.

Monreal, M., S.M Berch and M.L. Berbee, 1999. Molecular diversity of ericoid mycorrhizal fungi. Can. J. Bot. 77: 1580-1594.

Negrave, R. and C.E. Prescott. 2007. Growth and nutrition of juvenile conifer plantations with different fertilization and stand density combinations on northern Vancouver Island. Can. J. For. Res. (In press).

Northup, R.R., Y. Zengshou, R.A. Dahlgren and K.A. Vogt. 1995. Polyphenol control of nitrogen release from pine litter. Nature 377: 227-229.

Prescott, C.E., B.E. Kishchuk and G.F. Weetman. 1995. Long-term effects of repeated $\mathrm{N}$ fertilization and straw application in a jack pine forest. 3. Nitrogen availability in the forest floor. Can. J. For. Res. 25: 1991-1996.

Prescott, C.E., M.A. McDonald and G.F. Weetman. 1993. Availability of $\mathrm{N}$ and $\mathrm{P}$ in the forest floors of adjacent stands of western red cedar-western hemlock and western hemlock - amabilis fir on northern Vancouver Island. Can. J. For. Res. 23: 605-610.

Prescott, C.E. and L. Vesterdal. 2005. Effects of British Columbia tree species on forest floor chemistry. In O. Menyailo and D. Binkley (eds.). Trees and Soil Interactions, Implications to Global Climate Change. NATO Science Series. Kluwer Academic.

Prescott, C.E., L. Vesterdal, J. Pratt, K.H. Venner, L.M. de Montigny and J.A. Trofymow. 2000. Nutrient concentrations and nitrogen mineralization in forest floors of single species conifer plantations in coastal British Columbia. Canadian Journal of Forest Research 30: 1341-1352.

Prescott, C.E. and G.F. Weetman (eds.). 1994. Salal Cedar Hemlock Integrated Research Program: A Synthesis. Faculty of Forestry, UBC, Vancouver, BC. 85 p.

Prescott, C.E. and L.M. Zabek. 1997. Growth response and nutrient availability in western redcedar plantations following amendment with fish-wood compost and straw. Can. J. For. Res. 27: 598-602.

Price, D.T., T.A. Black and F.M Kelliher. 1986. Effects of salal understory removal on photosynthetic rate and stomatal conductance of young Douglas-fir trees. Can. J. For. Res. 16: 90-97.

Province of British Columbia. 2002. Salal Complex (Operational Summary for Vegetation Management). BC Ministry of Forests, Forest Practices Branch, Victoria, BC. 11 p.

Read, D.J. 1984. Interactions between ericaceous plants and their competitors with special reference to soil toxicity. Aspects Appl. Biol. 5: 195-209.

Sabhasri, S. 1961. An ecological study of salal (Gaultheria shallon). $\mathrm{PhD}$ thesis. Univ. Wash. Seattle, Wash.

Tappeiner, J.C., II, J.C. Zasada, D.W. Huffman, L.M. Ganio. 2001. Salmonberry and salal annual aerial stem production: the maintenance of shrub cover in forest stands. Can. J. For. Res. 31: 1629-1638. Vihanek, R.E. 1985. The effects of slashburning on the growth and nutrition of young Douglas-fir plantations in some dry, salal dominated ecosystems. M.Sc. thesis. Univ. B.C., Vancouver, BC. 98 p.

Weber, A., B. Gilbert, J.P. Kimmins and C.E. Prescott. 2003. Factors limiting the early survivorship of western redcedar on northern Vancouver Island. Can. J. For. Res. 33 :854-861.

Weetman, G.F., L.C. Dallaire and R. Fournier. 1995. Long-term effects of repeated $\mathrm{N}$ fertilization and straw application in a jack pine forest. 1. Twenty-two-year growth response. Can. J. For. Res. 25: $1978-1983$.

Weetman, G.F., R. Fournier, J. Barker, E. Schnorbus-Panozzo and A. Germain. 1989a. Foliar analysis and response of fertilized chlorotic Sitka spruce plantations on salal-dominated cedar-hemlock cutovers on Vancouver Island. Can. J. For. Res. 19: 1501-1511.

Weetman, G.F., R. Fournier, J. Barker, and E. Schnorbus-Panozzo. 1989b. Foliar analysis and response of fertilized chlorotic western hemlock and western red cedar reproduction on salal-dominated cutovers on Vancouver Island. Can. J. For. Res. 19: 1512-1520.

Weetman, G.F., R. Fournier, E. Schnorbus-Panozzo and J. Barker. 1990. Post-burn nitrogen and phosphorus availability of deep humus soils in coastal British Columbia cedar/hemlock forests and the use of fertilization and salal eradication to restore productivity. In S.P. Gessel, D.S. Lacate, G.F. Weetman and R.F. Powers (eds.). Sustained Productivity of Forest Soils. Proc. 7th N. Amer. Forest Soils Conf., Faculty of Forestry, University of British Columbia, Vancouver, BC. pp. 451-499.

Xiao, G. 1994. The role of root-associated fungi in the dominance of Gaultheria shallon. Ph.D. Thesis. Dept. Botany, University of British Columbia, Vancouver, BC. 137 p.

Xiao, G. and S.M. Berch. 1999. Organic nitrogen use by salal ericoid mycorrhizal fungi from northern Vancouver Island and impacts on growth in vitro of Gaultheria shallon. Mycorrhiza 9: 145-149. 